\title{
The economic burden of musculoskeletal disorders on the Italian social security pension system estimated by a Monte Carlo simulation
}

\author{
S. Russo ${ }^{1,2}$, T.T. Mariani ${ }^{3}$, R. Migliorini ${ }^{3}$, A. Marcellusi ${ }^{1,4}$, F.S. Mennini ${ }^{1,5}$ \\ ${ }^{1}$ Economic Evaluation and HTA (EEHTA), Centre for Economic and International Studies (CEIS), Tor Vergata \\ University, Rome, Italy; ${ }^{2}$ Department of Occupational Medicine, formerly Italian National Institute for \\ Occupational Safety and Prevention (ISPESL) - Italian National Institute for Insurance against Occupational \\ Accidents (INAIL), Rome, Italy; ${ }^{3}$ Office of General Forensic Coordination, Italian National Social Security \\ Institute (INPS), Rome, Italy; ${ }^{4}$ Department of Statistics, La Sapienza University, Rome, Italy; \\ ${ }^{5}$ Department of Accounting and Finance, Kingston University, London, UK
}

\begin{abstract}
SUMMARY
The aim of the study is to estimate the pension costs incurred for patients with musculoskeletal disorders (MDs) and specifically with rheumatoid arthritis (RA) and ankylosing spondylitis (AS) in Italy between 2009 and 2012.

We analyzed the database of the Italian National Social Security Institute (Istituto Nazionale Previdenza Sociale i.e. INPS) to estimate the total costs of three types of social security benefits granted to patients with MDs, RA and AS: disability benefits (for people with reduced working ability), disability pensions (for people who cannot qualify as workers) and incapacity pensions (for people without working ability).

We developed a probabilistic model with a Monte Carlo simulation to estimate the total costs for each type of benefit associated with MDs, RA and AS. We also estimated the productivity loss resulting from RA in 2013. From 2009 to 2012 about 393 thousand treatments were paid for a total of approximately $€ 2.7$ billion. The annual number of treatments was on average 98 thousand and cost in total $€ 674$ million per year. In particular, the total pension burden was about $€ 99$ million for RA and $€ 26$ million for AS. The productivity loss for AR in 2013 was equal to $€ 707,425,191$ due to $9,174,221$ working days lost.

Our study is the first to estimate the burden of social security pensions for MDs based on data of both approved claims and benefits paid by the national security system.

From 2009 to 2012, in Italy, the highest indirect costs were associated with disability pensions (54\% of the total indirect cost), followed by disability benefits ( $44.1 \%$ of cost) and incapacity pensions ( $1.8 \%$ of cost). In conclusion, MDs are chronic and highly debilitating diseases with a strong female predominance and very significant economic and social costs that are set to increase due to the aging of the population.
\end{abstract}

Key words: Social security system; musculoskeletal disorders; rheumatoid arthritis; ankylosing spondylitis.

Reumatismo, 2015; 67 (2): 45-56

\section{INTRODUCTION}

$\mathrm{M}$ usculoskeletal conditions (MSCs) are among the most widespread diseases that affect people of all ages and ethnic groups, causing disabilities and often handicaps. As a consequence, they represent one of the main expense items for the healthcare service and social security system. A sample study on the Italian adult population (1) revealed that about $27 \%$ of the sample had some MDs. Another study
(2) estimated that in Europe 103 million people are affected by these diseases which are one of the leading causes for disability. The definition of MDs is generic, as it includes a variety of different conditions that cause pain or discomfort in bones, joints, muscles or surrounding structures.

A study conducted in 2003 by the Centers of Disease Control and Prevention (3) estimated that in the United States $\$ 80$ billion were spent to cover for direct costs and $\$ 47$ billion for indirect costs related to rheumat-
Corresponding author: Simone Russo Via Giacomo Boni, 1 00162 Rome, Italy E-mail: simone.russo82@hotmail.it 
ic diseases, which accounted for $1.2 \%$ of the gross domestic product and increased by $24 \%$ from 1997 to 2003 .

Another study on RA conducted by Leardini (4) in 2002 estimated that in Italy indirect costs vary on average from $€ 2100$ for class I to $€ 17,000$ for class IV per patient. Turchetti et al. (5) in 2014 estimated for RA a total cost of $€ 3.5$ billion ( $€ 2.4$ billion for direct costs and $€ 1.1$ billion for indirect costs) and $€ 740$ million due to total patient productivity loss which translates in $€ 2831$ per patient.The objective of our study was to estimate the number of benefits provided and the associated pension costs incurred by the community for MSCs (it should be reminded that in Italy the social security system is funded by the state). Data were taken from the INPS database that includes 18 diseases in the category of MSCs, among which arthrosis, RA and ankylosing spondylitis (AS).

Due to the economic impact of treatments required by autoimmune diseases on the National Health Service, we analysed in particular data concerning RA [Rheumatoid arthritis and rheumatic fever, group 16, disease code 231 by INPS's disease nosological code (6)] and AS [Ankylosing spondylitis and spondylosis, group 16, disease code 232 by INPS's disease nosological code (6)].

The latest report of the National Observatory on the Use of Medicines (OsMED) (7) shows that in Italy the burden for antitumor necrosis factor- $\alpha$ biologic drugs, which are also utilized to treat the abovementioned diseases, account for $3 \%$ of the pharmaceutical expenditure. We will focus in particular on three types of benefits provided by INPS: the disability benefit (DB) granted to workers with reduced working capacity, the incapacity pension (IP) for workers unable to work, and the disability pension (DP) granted to citizens unable to work and to support themselves.

We also estimated the costs due to the loss of productivity caused by absenteeism of patients affected by RA, because out of these three diseases it is the one for which the highest number of benefits were provided.

\section{METHODOLOGY}

\section{Social security benefits for incapacity pensions}

In case of an accident or illness, after social security contributions have been paid for five years three of wich in the last five years, all categories registered with INPS have the right to benefit from DB or IP. The Italian law (L. 222/84) establishes the regulatory criteria with which they are granted. At the INPS's forensic centres, doctors assess the state of disability or incapacity of workers affected by serious illnesses. The assessment is based exclusively on forensic criteria and does not include any assessment of socio-economic factors or other aspects.

\section{Disability benefit}

It is a financial benefit for all categories of workers registered with INPS (mainly private sector employees and self-employed workers) with a working capacity reduced to less than one-third due to physical or mental illness, who applied for it after having paid social security contributions for five years three of wich in the last five years. The applicant is not required to cease work. The allowance is paid for a period of three years and can be renewed for further 3-year periods. After three consecutive awards, the disability allowance is confirmed automatically. This type of pension is funded and paid by INPS.

\section{Incapacity pension}

It is a financial benefit for all categories of workers registered with INPS (mainly private sector employees and self-employed workers) who applied for it after having paid social security contributions for five years three of wich in the last five years and were confirmed to be in a state of have of absolute and permanent inability to work. Retirement from work is mandatory. This type of pension is funded and paid by INPS.

\section{Disability pension}

The Italian Constitution (art. 38) provides that citizens unable to work and to support themselves, even if not belonging to any workers' category, are entitled to receive 
income-support allowances and benefit from a DP granted by the social security system. This type of pension is funded by the taxpayer and paid by INPS.

\section{Italian National Social Security Institute (INPS) data}

The estimate of the benefits granted is based on the claims approved by INPS (8-10) and the total benefits provided in a single year (11). In particular, the INPS database contains the number of approved claims for DB and IP from 2001 to 2012 and for DP from 2011 to 2012 associated with the main twenty disease groups, including the two specific MSDs under study. The data concerning approved claims refer to clinical situations where one or more MSCs is

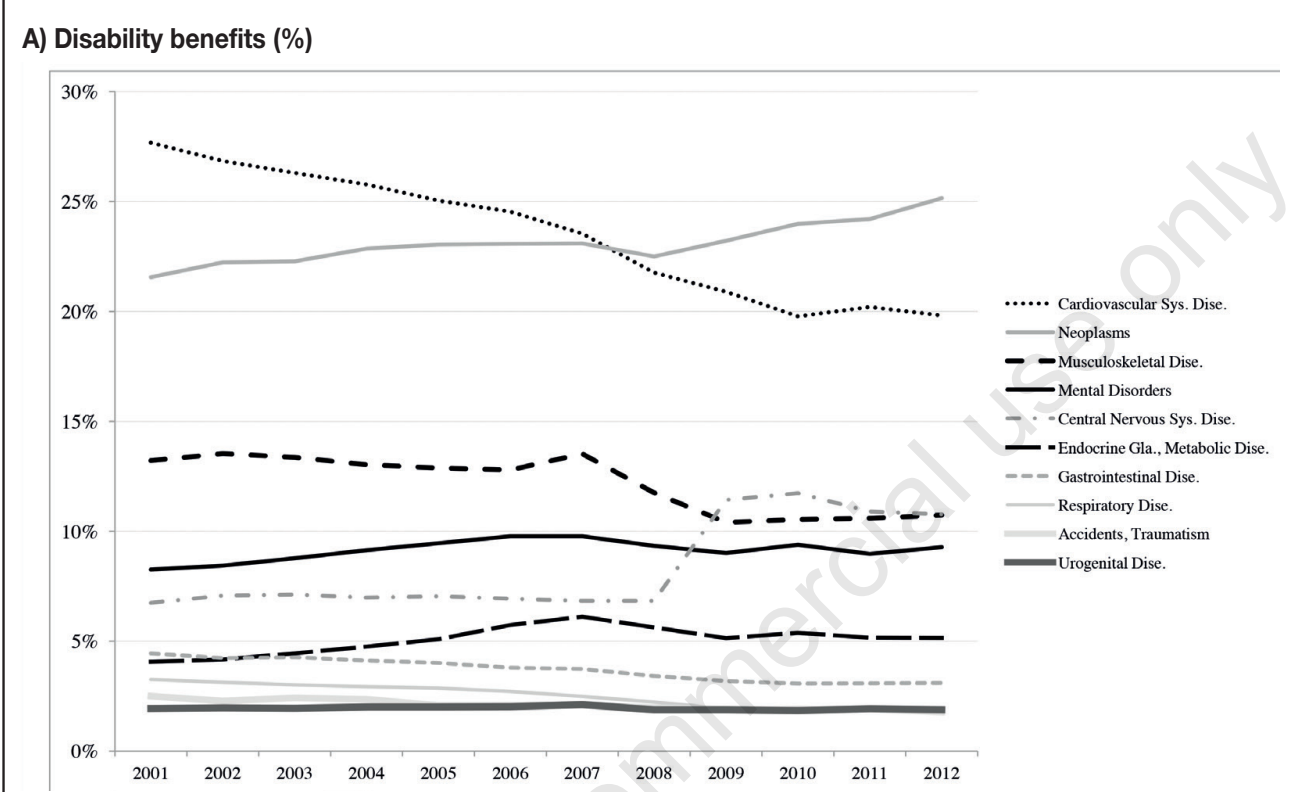

B) Incapacity pensions (\%)

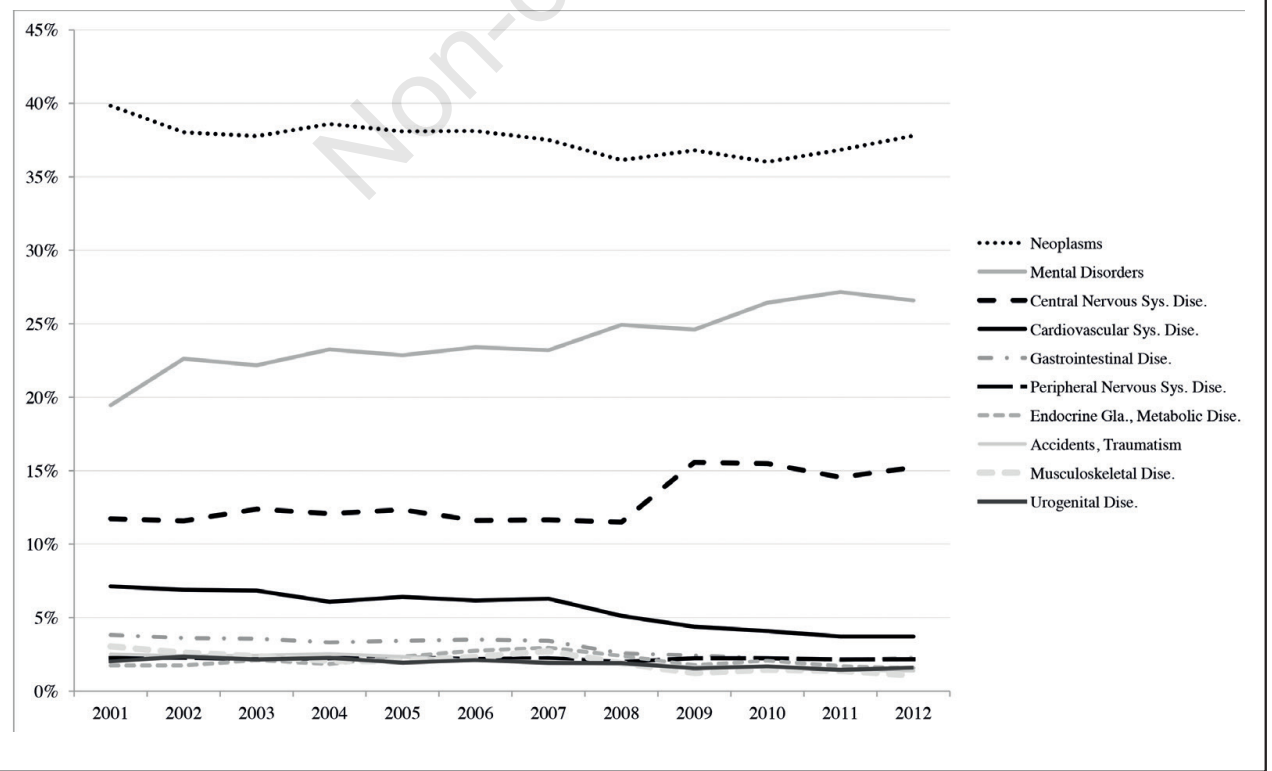

Figure 1 - Trend of approved claims of disability benefits $(A)$ and incapacity pensions $(B)$ for the main groups of diseases from 2001 to 2012. Source: INPS. 


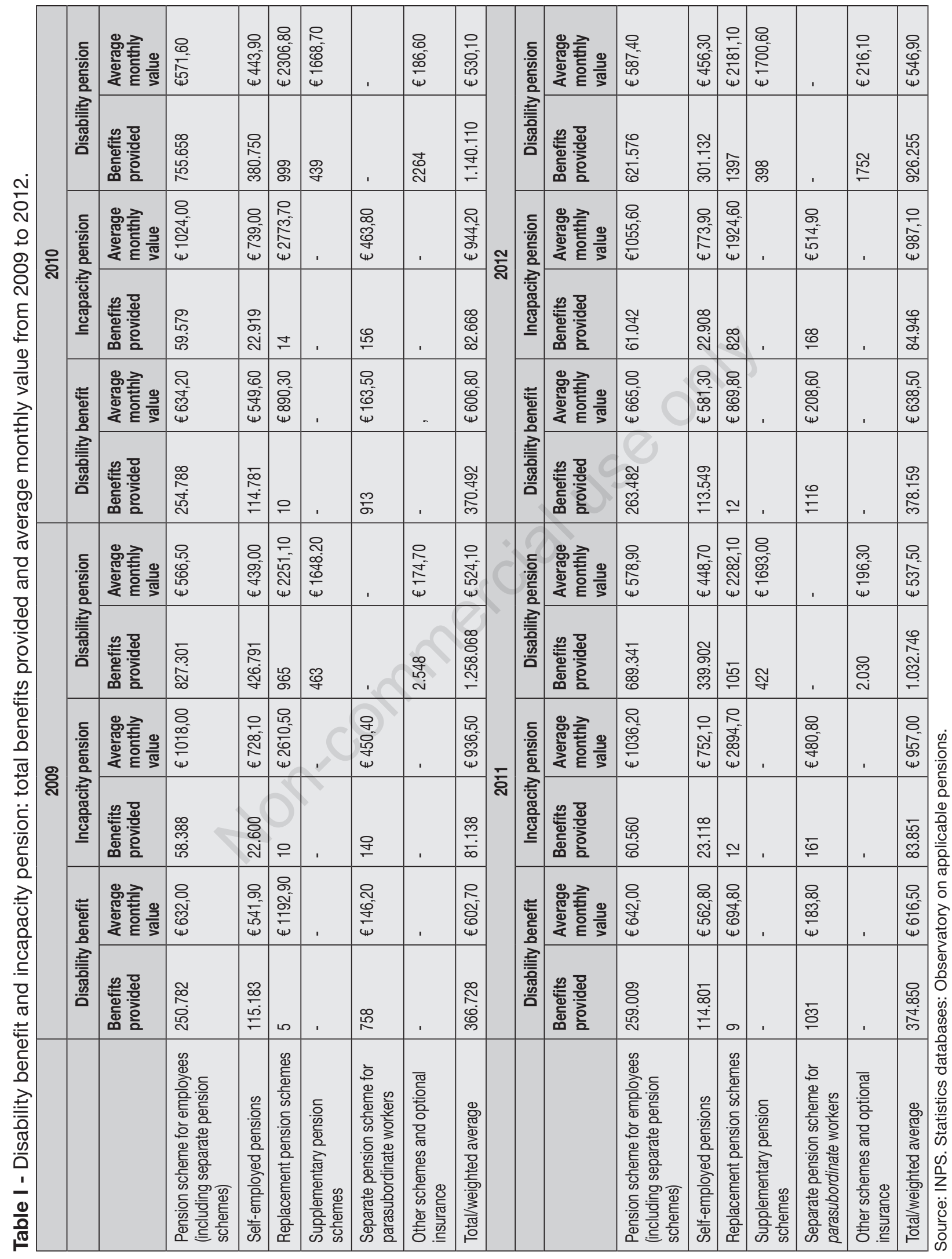


reported as one of the disabling pathologies after an assessment on the state of the physical and mental health of the applicant conducted by the INPS medical committee and the approval of the application based on the presence of one or more disabling diseases. Figure 1 shows that MSCs account for the third group of diseases in terms of approved claims for DB and the tenth cause for IP from 2001 to 2012. The estimate of the costs per type of benefit was conducted on the basis of the average monthly values per kind of scheme (11) (Table I).

\section{Estimate of applicable allowances}

Estimate of applicable allowances for disability benefits and disability pensions

As provided for by Italian laws $(12,13)$, the DB is granted for a three-year period and may be extended for further 3-year periods. This framework makes it possible to develop a method to estimate applicable benefits based on their eligible periods by adding the approved claims of a given disease $i$ in a year $t$ to the claims approved in the previous two years, as expressed by the following formula (Eq. 1):

$$
\text { Applicable }_{i, t}=\Sigma_{l=0}^{2} \text { Approved }_{t-i} \quad \text { (1) } \text { Applicable }_{i, t}=\text { Applicable }_{t} * \% \text { Approved }_{i, t}
$$

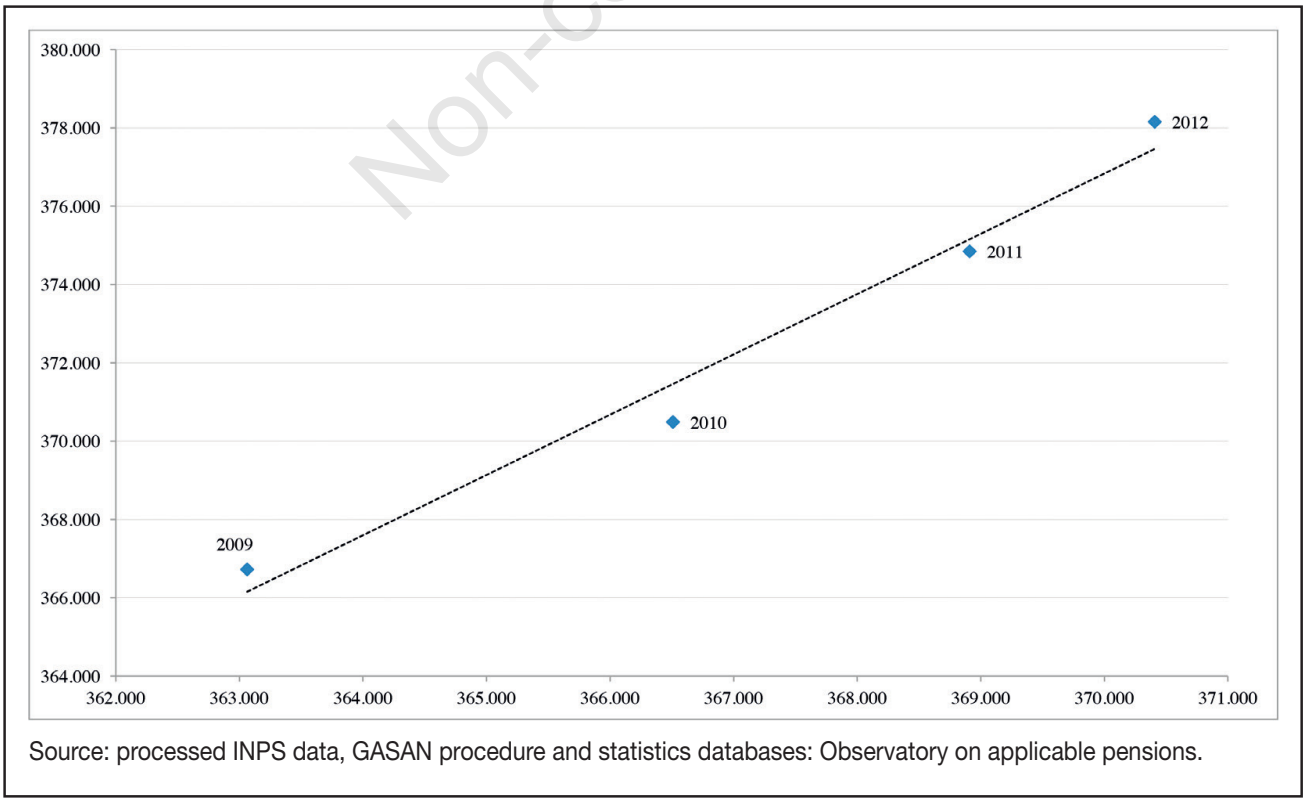

Figure 2 - Linear regression model with total disability benefit estimated (independent variable) and total disability benefit provided (dependent variable). $R^{2}=0.975$. 


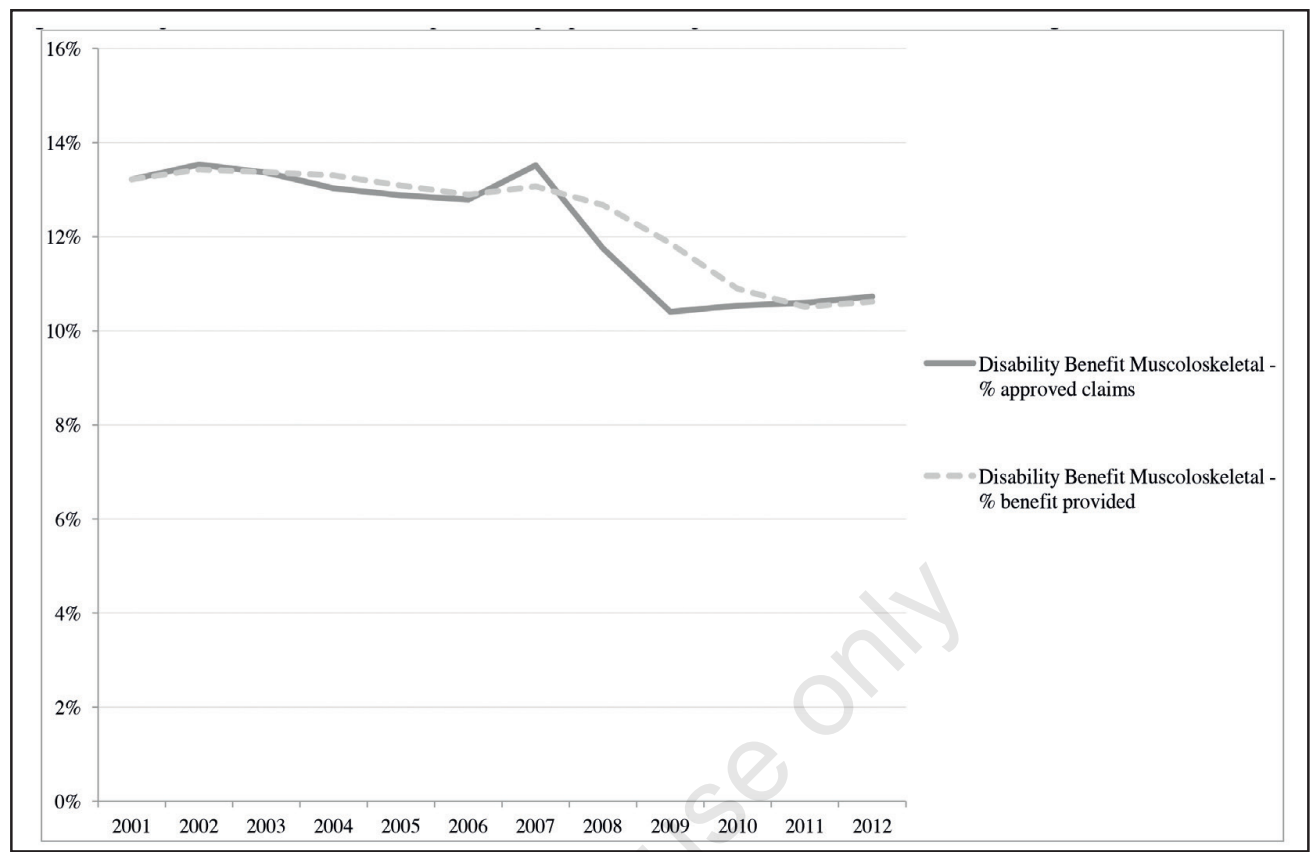

Figure 3 - Disability benefits: percentage distribution of estimated applicable benefits and approved claims. Musculoskeletal conditions.

where Applicable ${ }_{i, t}$ is the number of benefits provided for disease $i$ in year $t, A p p l i$ cable is the total number of benefits of year $t$ and \% Approved $i, t$ is the percentage value of the approved claims for disease $i$ in year $t$ out of the total approved claims.

The estimates of total benefits for these two categories were then broken down according to the percentage distribution indicated in Table I and multiplied by the average annual amounts on the assumption that total benefits paid and MSDs have the same percentage distributions per kind of scheme.

\section{Estimate of current benefits for disability pension}

To estimate this kind of allowance the same method identified for IP can be applied, but for 2011 and 2012 only, as the information about approved claims for MSDs in other years is not available. Therefore, the value is equal to the percentage of approved claims for MSCs out of the total of approved claims multiplied by the DP granted for all diseases.

For 2009 and 2010 the total applicable benefits were estimated through DB and
IP trends. The percentage of granted DP for MSCs in a year is indicated in Table II and was estimated as follows: i) the difference between the percentage of approved claims for MSCs out of the total approved claims and the same percentage for the following year is calculated for DB and IP respectively (for example: 2010 vs 2011 and 2009 vs 2010); ii) the average differences of the two benefits are calculated; iii) the average values are added to the percentage of granted DP for MSCs in the next year (example for 2010: percentage of granted DP for MSCs in 2011 added with average differences between DB and IP in 2010).

Once granted DP percentages are available, the benefits provided for MSCs can be obtained by applying the same methodology used for 2011 and 2012.

\section{Statistical analysis: Monte Carlo simulation}

The parameters used to estimate the costs incurred by INPS for social security benefits were assumed to be subject to some degree of uncertainty. For this reason, a Monte Carlo simulation was performed. It consists in a simultaneous variation of the 
Table II - Estimate of incapacity pensions for musculoskeletal conditions

\begin{tabular}{|c|c|c|c|c|}
\hline & 2009 & 2010 & 2011 & 2012 \\
\hline Disability pensions, benefits provided - Total & 1.258 .068 & 1.140 .110 & 1.032 .746 & 926.255 \\
\hline Disability pensions, approved benefits - Total & - & - & 220.784 & 428.224 \\
\hline $\begin{array}{l}\text { Disability pensions, approved claims - } \\
\text { Musculoskeletal cond. }\end{array}$ & - & - & 11.847 & 19.678 \\
\hline $\begin{array}{l}\text { Disability benefits, \% appr. Claims for } \\
\text { musculosk. cond. on tot. approved }\end{array}$ & $10,41 \%$ & $10,53 \%$ & $10,59 \%$ & $10,73 \%$ \\
\hline Disability benefits - difference vs next year & $-0,13 \%$ & $-0,06 \%$ & $0,00 \%$ & $0,00 \%$ \\
\hline $\begin{array}{l}\text { Incapacity pensions, \% approved claims for } \\
\text { musculosk. cond. on tot. approved }\end{array}$ & $1,22 \%$ & $1,46 \%$ & $1,37 \%$ & $1,07 \%$ \\
\hline Incapacity pensions - difference vs next year & $-0,23 \%$ & $0,09 \%$ & $0,00 \%$ & $0,00 \%$ \\
\hline $\begin{array}{l}\text { Disability pensions - \% estimate - } \\
\text { Musculoskeletal conditions }\end{array}$ & $5,2 \%$ & $5,4 \%$ & $5,4 \%$ & $4,6 \%$ \\
\hline $\begin{array}{l}\text { Disability pensions - benefits provided - } \\
\text { Musculoskeletal conditions }\end{array}$ & 65.433 & 61.357 & 55.416 & 42.564 \\
\hline
\end{tabular}

parameters used in the model according to a probability distribution (14). This simulation generated a series of observations of the phenomenon under examination in order to evaluate the range of variation. First of all we have identified the sources of parameter uncertainty: i) total benefits provided; ii) percentage distribution per kind of scheme; iii) yearly values per kind of scheme.

We assigned a probability distribution to each parameter. The distributions were selected to comply with the characteristics of this data (15).

For the benefits provided and the yearly values we assigned a gamma distribution, generally used for values that have the constraint of non-negativity, while we used the beta distribution for the percentage distributions per kind of scheme that assume values between 0 and 1 .

Once we assigned probability distributions to the parameters, the uncertainty was extended to the whole model through a Monte Carlo simulation. For each run of the model, the software extracted a random value for each parameter according to the assigned distribution and recorded the results of each simulation.

The model was then iterated with 10,000 simulations. We applied this method to obtain the confidence intervals and more robust estimates of the current benefits and the associated costs.

Calculation of costs due to the loss

of productivity

The loss of productivity of workers affected by RA was estimated on the basis of the data made available by the National Institute of Statistics (Istat) $(16,17)$, the Center for Social Investment Studies (Censis) (18) and various scientific publications $(4,19)$. As shown in Table III, this information was intended to estimate the remuneration of a single work day and the number of lost work days, broken down by gender, disease stage and job. These data refer to different years, therefore we assume that they are unchanged as of 2013, which is the reference year for the estimate of costs associated with the loss of productivity.

\section{RESULTS}

\section{Estimate of social security costs}

Estimate of benefits provided and costs for disability benefits, disability pensions and incapacity pensions

Figure 4A reports the estimates of the benefits provided. DP reports 228,372 applicable benefits in the four years under study, followed by DB with 161,154 and IP with 4252 benefits. The trends of DB and IP are rather stable, while for DP there was a decrease in benefits paid mirroring the trend of the total benefits provided for DP (Table 
Table III - Estimate of costs for loss of productivity. Data used.

\begin{tabular}{|c|c|c|c|c|c|}
\hline \multirow[t]{2}{*}{ Information } & \multirow[t]{2}{*}{ Source } & \multicolumn{2}{|c|}{$\begin{array}{l}\text { Gross salary per } \\
\text { working hour }\end{array}$} & \multicolumn{2}{|c|}{ Yearly working hours } \\
\hline & & Men & Women & Men & Women \\
\hline Unqualified jobs & Istat, Salary system, 2010 & $€ 11,34$ & $€ 9,76$ & 1770 & 1412 \\
\hline Specialized farmers & Istat, Salary system, 2010 & $€ 11,79$ & $€ 10,11$ & 1857 & 1566 \\
\hline $\begin{array}{l}\text { Craftsmen and specialized } \\
\text { workers }\end{array}$ & Istat, Salary system, 2010 & $€ 12,46$ & $€ 10,17$ & 1882 & 1562 \\
\hline Employees & Istat, Salary system, 2010 & $€ 16,83$ & $€ 14,36$ & 1902 & 1781 \\
\hline Managers & Istat, Salary system, 2010 & $€ 46,10$ & $€ 35,24$ & 1929 & 1741 \\
\hline \multirow{2}{*}{$\begin{array}{l}\text { Jobs in commercial } \\
\text { activities and services }\end{array}$} & Istat, Salary system, 2010 & $€ 12,92$ & $€ 11,01$ & 1882 & 1577 \\
\hline & & \multicolumn{2}{|c|}{ Men } & \multicolumn{2}{|c|}{ Women } \\
\hline Housewife & Censis, Anmar, SIR, 2008 & \multicolumn{2}{|c|}{$0,0 \%$} & \multicolumn{2}{|c|}{$51,6 \%$} \\
\hline Farmers & Censis, Anmar, SIR, 2008 & \multicolumn{2}{|c|}{$1,7 \%$} & \multicolumn{2}{|c|}{$0,4 \%$} \\
\hline Worker & Censis, Anmar, SIR, 2008 & \multicolumn{2}{|c|}{$10,2 \%$} & \multicolumn{2}{|c|}{$2,1 \%$} \\
\hline Employee/teacher & Censis, Anmar, SIR, 2008 & \multicolumn{2}{|c|}{$13,6 \%$} & \multicolumn{2}{|c|}{$16,4 \%$} \\
\hline Professional/manager & Censis, Anmar, SIR, 2008 & \multicolumn{2}{|c|}{$2,8 \%$} & \multicolumn{2}{|c|}{$1,5 \%$} \\
\hline Craftsman/trader & Censis, Anmar, SIR, 2008 & \multicolumn{2}{|c|}{$7,9 \%$} & \multicolumn{2}{|c|}{$1,7 \%$} \\
\hline Entrepreneur & Censis, Anmar, SIR, 2008 & \multicolumn{2}{|c|}{$1,7 \%$} & \multicolumn{2}{|c|}{$0,2 \%$} \\
\hline Unemployed & Censis, Anmar, SIR, 2008 & \multicolumn{2}{|c|}{$0,6 \%$} & \multicolumn{2}{|c|}{$0,2 \%$} \\
\hline $\begin{array}{l}\text { Italian population } \\
\text { at } 31 / 12 / 2012\end{array}$ & Istat & \multicolumn{2}{|c|}{28.726 .599} & \multicolumn{2}{|c|}{30.667 .608} \\
\hline $\begin{array}{l}\text { Rheumatoid arthritis } \\
\text { prevalence }\end{array}$ & Rossini 2014 & \multicolumn{2}{|c|}{$0,23 \%$} & \multicolumn{2}{|c|}{$0,57 \%$} \\
\hline Work days in a year & & \multicolumn{4}{|c|}{253} \\
\hline Dropout from work & Leardini 2002 & \multicolumn{4}{|c|}{$12,8 \%$} \\
\hline
\end{tabular}

I), which fell by $35 \%$ from 2009 to 2012 . As far as the estimate of costs is concerned, Figure 4B shows that DP generated an expenditure of $€ 1.4$ billion in the four years under study, followed by DB with about $€ 1.2$ billion and IP with about $€ 49$ million. The trends are rather stable for IP, while a slight decrease is reported for DB over 2010 and 2011 and for DP the total costs fell by $32 \%$ from 2009 to 2012 .

The estimate of the two specific conditions shows that RA is the disease with the highest number of benefits provided, approximately 13,000 from 2009 to 2012 (Figure $4 \mathrm{C}$ ), along with the highest costs, amounting to about €99 million (Figure 4D). As far as AS is concerned, about 3400 benefits were provided over this four-year period for a total of approximately €26 million. Estimate of total costs

Figure 5A reports the sum of the estimates of the three benefits in terms of costs and granted allowances. Between 2009 and 2012 the estimated average benefits provided per year were about 98,445 which were worth about $€ 674$ million, while the total benefits provided over the same four years were 393,778 with a total cost of $€ 2.6$ billion. The cost breakdown indicated in Figure 5B shows that $54 \%$ of MSC costs are generated by DP, about $44 \%$ by DB and a little less than $2 \%$ by IP.

Estimate of costs due to the loss of productivity

Table IV reports the results of the cost esti- 


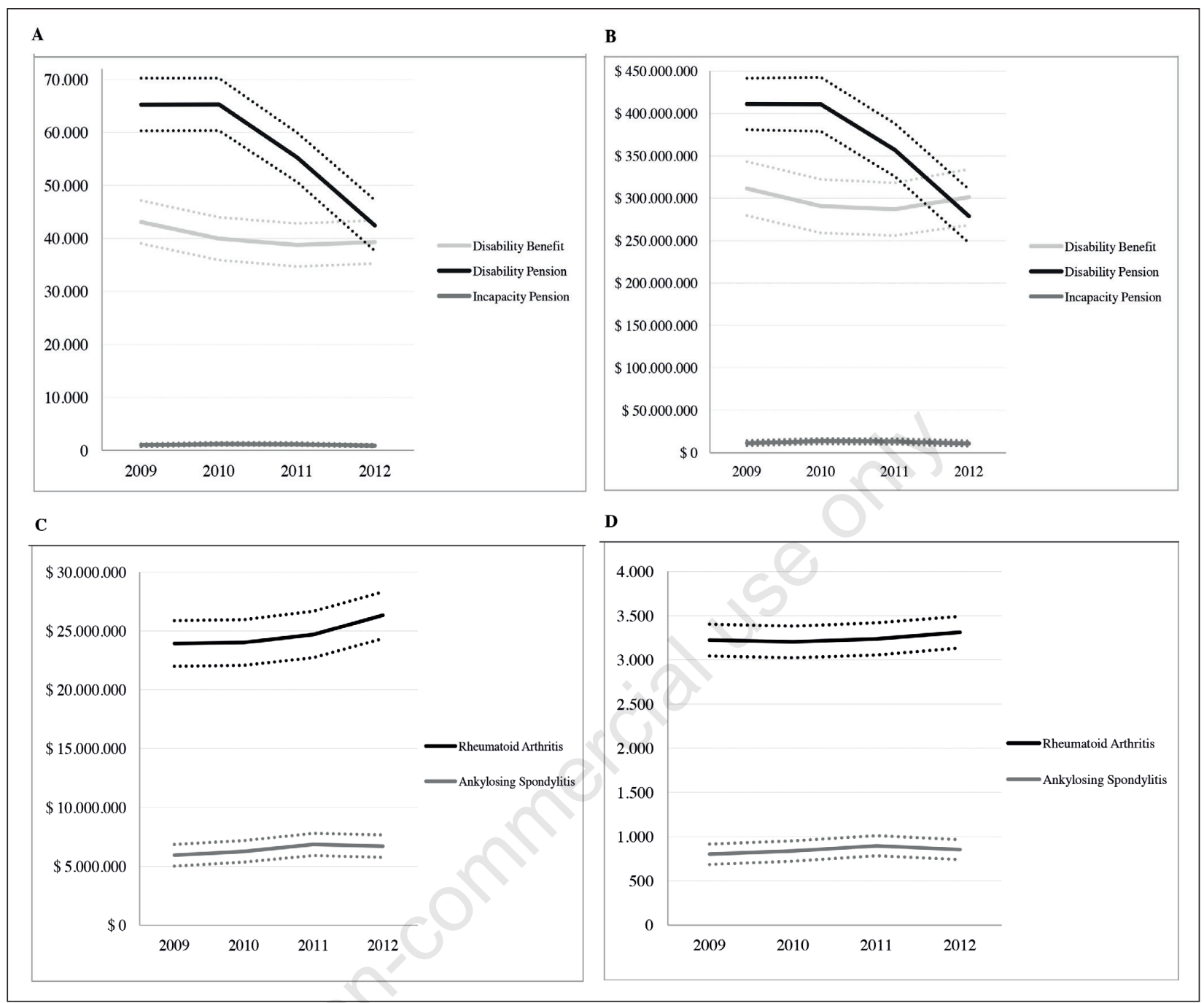

Figure 4 - Benefits provided and cost estimated. (A) Benefits provided for musculoskeletal disease and type of social security benefits. (B) Cost estimated for musculoskeletal disease and type of social security benefits. (C) Benefits provided to disability benefits and incapacity pensions for rheumatoid arthritis, ankylosing spondylitis. (D) Cost estimated of disability benefits and incapacity pensions for rheumatoid arthritis, ankylosing spondylitis.

mates for the loss of productivity. By comparing the two genders, the female population affected by RA is five times greater than the male one, considering that women represent about $72 \%$ of the people affected by the disease. $74 \%$ of them are employed. Overall, the estimate reports about 134 thousand employed people affected by RA, 22 thousand males and 112 thousand females. Lost work days were nearly 9 million (1.4 million for males and 7.3 million for females) amounting to about $€ 704$ million ( $€ 193$ million for males and $€ 511$ for females). Consequently the productivity loss per employed patient was €8840 for males and $€ 4552$ for female.

\section{CONCLUSIONS}

The MSCs involve quite relevant economic and social costs due to the chronic nature of these diseases.

This study is the first attempt an estimate of pension costs for MSCs using data of claims approved and benefits provided by INPS. These costs are particularly significant due to the benefits provided. In 


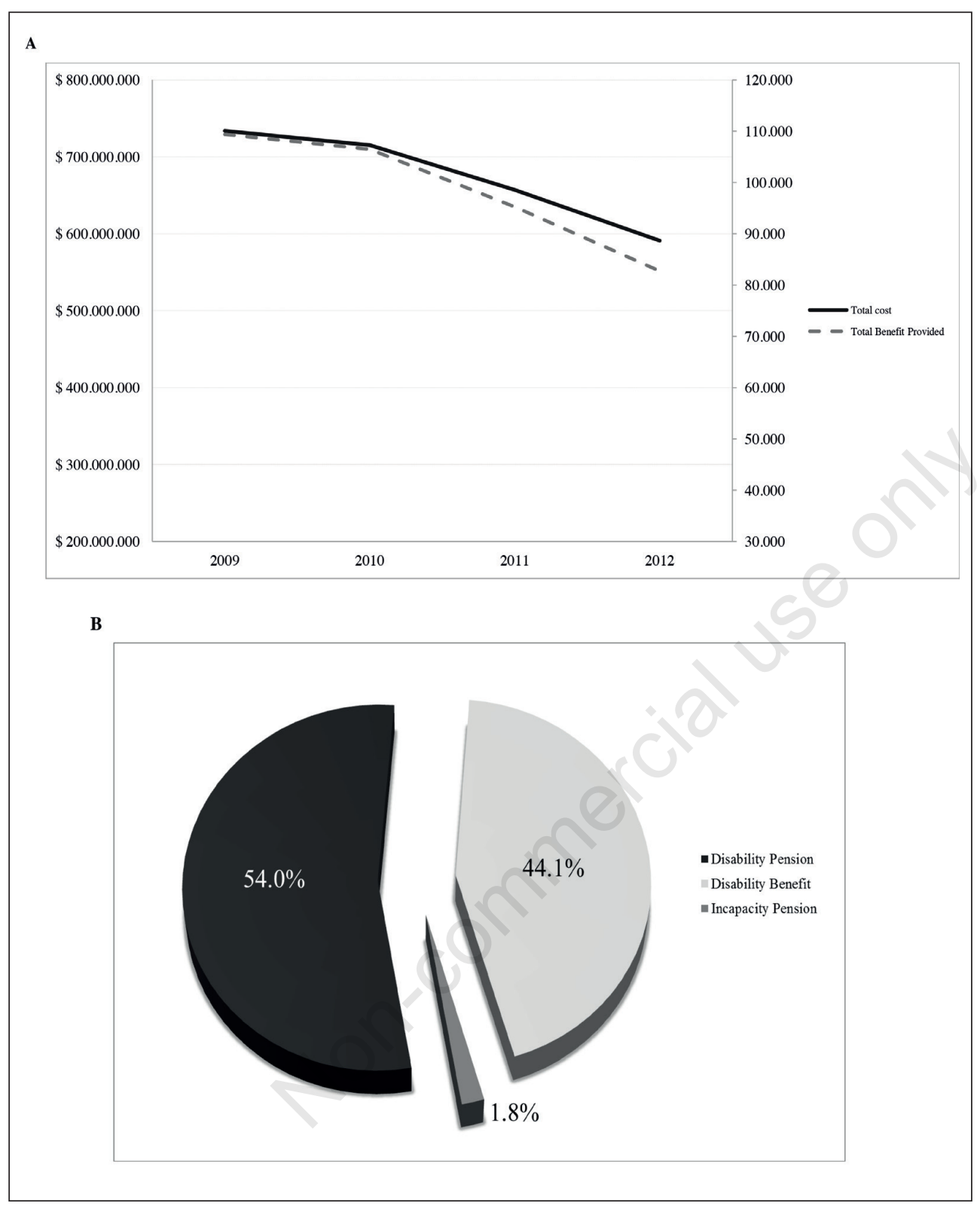

Figure 5 - (A) Sum of cost estimates and total benefits provided. (B) Cost breakdown from 2009 to 2012: disability benefit, disability pension and incapacity pension.

particular, DPs with an average of about 57,000 benefits provided translated into a cost of $€ 364$ million, followed by DBs with 40,000 benefits provided with a cost of $€ 298$ million and 1000 IPs with a cost of $€ 12$ million. The productivity loss for RA involves a total of approximately 134,000 people, $84 \%$ of whom are women, for a total of about 9 million lost working days and a cost of slightly over $€ 700$ million.

However our study has some limitations. It was not possible to consider in estimate of DBs the survival of patients with MSCs between the time when the claims were accepted and the following three years in which the benefit was granted. The IPs provided were estimated without taking into account the different probabilities of survival for the pathology groups classified according to INPS which involve some differences between the percentage distributions for pathological groups of approved claims and the distribution of the benefits provided. The estimate of benefits for DP 
Table IV - Cost estimate of productivity loss. Results.

\begin{tabular}{|l|l|l|l|l|}
\hline & $\begin{array}{l}\text { Employed male } \\
\text { population with } \\
\text { rheumatoid arthritis }\end{array}$ & $\begin{array}{l}\text { Lost work } \\
\text { days }\end{array}$ & $\begin{array}{l}\text { Loss of } \\
\text { productivity }\end{array}$ & $\begin{array}{l}\text { Loss of } \\
\text { productivity } \\
\text { for employed }\end{array}$ \\
\hline $\begin{array}{l}\text { Total male population } \\
\text { with rheumatoid } \\
\text { arthritis }\end{array}$ & 21.836 & 1.419 .323 & $€ 193.020 .730$ & $€ 8.840$ \\
\hline & $\begin{array}{l}\text { Employed female } \\
\text { population with } \\
\text { rheumatoid arthritis }\end{array}$ & $\begin{array}{l}\text { Lost work } \\
\text { days }\end{array}$ & $\begin{array}{l}\text { Loss of } \\
\text { productivity }\end{array}$ & $\begin{array}{l}\text { Loss of } \\
\text { productivity } \\
\text { for employed }\end{array}$ \\
\hline $\begin{array}{l}\text { Total female population } \\
\text { with rheumatoid } \\
\text { arthritis }\end{array}$ & \begin{tabular}{l}
112.341 \\
\hline $\begin{array}{l}\text { Total population with } \\
\text { rheumatoid arthritis }\end{array}$
\end{tabular} & $\begin{array}{l}734.302 .173 \\
€ 511.352 .187\end{array}$ & $€ 4.552$ \\
\hline
\end{tabular}

has the same limits of the estimation of IP and is also based on data referring to two single years. The DB and IP provided by INPS do not include all the existing job categories (mainly private sector employees and self-employed workers, for example the public sector workers were not considered). Finally, the data used for the calculations on the loss of productivity refer to different years.

In conclusion, MSCs are highly debilitating and chronic diseases with a strong female prevalence. Despite some pension costs were reduced in recent years, they still require a considerable use of funds that could even increase due to the aging population. In order to prevent and minimize the consequences of this scenario, more appropriate prescriptions and a faster access to innovative treatments would reduce the costs incurred by the social security system and improve the effectiveness of interventions, although Italy compared with the rest of the EU countries has the greatest delay in terms of availability of innovative technologies (20).

Conflict of interest: Dr. Russo, Dr. Mariani, Dr. Migliorini Dr. Marcellusi and Dr. Mennini have nothing to disclose.

\section{REFERENCES}

1. Salaffi F, De Angelis R, Grassi W; Marche Pain Prevalence; Investigation Group (MAPPING) study. Prevalence of musculoskeletal conditions in an Italian population sample: results of a regional community-based study. I. The MAPPING study. Clin Exp Rheumatol. 2005; 23: 819-28.

2. Jones R. Manifesto for the third millennium. Patient's Network 2000; 5: 23.

3. Centers for Disease Control and Prevention. Cost statistics; last reviewed: August 1, 2011. Available from: http:/www.cdc.gov/arthritis/ data_statistics/cost.htm

4. Leardini G, Salaffi F, Montanelli R, Gerzeli S, Canesi B. A multicenter cost-of-illness study on rheumatoid arthritis in Italy. Clin Exp Rheumatol. 2002; 20: 505-15.

5. Turchetti G, Bellelli S, Mosca M. The social cost of rheumatoid arthritis in Italy: the results of an estimation exercise. Reumatismo. 2014; 65: 271-7.

6. Mastrangelo G, Fadda E, Priolo G, Scoizzato L., Buja A. Indagine pilota conoscitiva sulle condizioni di salute e sicurezza negli ambienti di lavoro relativa ad una realtà regionale: Veneto. Available from: http://www.cgilverona.it/file/INDAGINE_ISPESL_VENETO.pdf

7. Agenzia Italiana del Farmaco (AIFA), Osservatorio Nazionale sull'Impiego dei Medicinali (OsMED). L'uso dei farmaci in Italia - Rapporto nazionale, anno 2013. Roma: Luglio 2014. Available from: http://www.agenziafarmaco.gov.it/sites/default/files/Rapporto_ OsMED_2013.pdf

8. Ranieri A, Ripepi L, Siviglia G. Giacenze anomale e bonifica listado: un problema e la sua soluzione. Rassegna Medicina Legale Previdenziale. 2002; XV: 64-80.

9. Osservatorio sulla condizione assistenziale dei malati oncologici; Federazione Italiana delle Associazioni di Volontariato in Oncologia (FAVO). $4^{\circ}$ Rapporto sulla condizione assistenziale dei malati oncologici - Roma, 15-20 maggio 2012 - VII Giornata nazionale del malato oncologico. Available from: http:// 
www.favo.it/quarto-rapporto/quarto-rapporto-2012.html

10. Osservatorio sulla condizione assistenziale dei malati oncologici; Federazione Italiana delle Associazioni di Volontariato in Oncologia (FAVO). $5^{\circ}$ Rapporto sulla condizione assistenziale dei malati oncologici - Roma, 16-19 maggio 2013 - VIII Giornata nazionale del malato oncologico. Available from: http://www. favo.it/quinto-rapporto/quinto-rapporto-2013. html

11. Istituto Nazionale Previdenza Sociale (INPS). Osservatori statistici. Available from: http:// www.inps.it/portale/default.aspx?sID $=\% 3 \mathrm{~b} 0 \%$ 3b6840\%3b\&lastMenu=6840\&iMenu=12\&i Nodo $=6840 \& p 4=2$

12. Parlamento Italiano. Legge 12 giugno 1984, n. 222. Revisione della disciplina della invalidità pensionabile. In: G.U. n. 165, 16/6/1984. Available from: http://www.normattiva.it/ uri-res/N2Ls?urn:nir:stato:legge:1984-06$12 ; 222$ ! vig=

13. Parlamento Italiano. Decreto Legislativo 30 dicembre 1992, n. 503. Norme per il riordinamento del sistema previdenziale dei lavoratori privati e pubblici, a norma dell'articolo 3 della legge 23 ottobre 1992, n. 421. In: G.U. n. 305, 30/12/1992 - Suppl. Ord. n. 137. Available from: http://www.normattiva.it/uri-res/ N2Ls?urn:nir:stato:decreto.legislativo:199212-30;503!vig=
14. Kalos MH, Whitlock PA. Monte Carlo symulation. Weinheim: Wiley-VCH Verlag $\mathrm{GmbH} \&$ Co. 2008.

15. Sculpher M. The use of a probabilistic sensitivity analysis for decision making: the example of drug-eluting stents. Seminar at Harvard Clinical Research Institute, 17th August 2004.

16. Istituto nazionale di statistica (Istat). Struttura delle retribuzioni. Anno 2010. Istat; febbraio 2013. Available from: http://www.istat.it/it/archivio/83362

17. Istituto nazionale di statistica (Istat). Popolazione residente al 1 gennaio 2012. Available from: http://demo.istat.it/pop2012/index3.html

18. Associazione Nazionale Malati Reumatici (ANMAR), Società Italiana di Reumatologia (SIR), fondazione Censis. Un percorso ad ostacoli - Primo rapporto sociale sull' artrite reumatoide. Roma: ottobre 2008. Available from: http://www.anmar-italia.it/images/stories/ PDF/Report_Sociale_AR.pdf

19. Rossini M, Rossi E, Bernardi D, Viapiana O, Gatti D, Idolazzi L, et al. Prevalence and incidence of rheumatoid arthritis in Italy. Rheumatol Int. 2014; 34: 659-64.

20. Russo P, Mennini FS, Siviero PD, Rasi G. Time to market and patient access to new oncology products in Italy: a multistep pathway from European context to regional health care providers. Ann Oncol. 2010; 21: 2081-7. 